\title{
Obesity, Hypertrichosis and Sex Steroids: Are these Factors Related to the Pilonidal Sinus Disease?
}

\author{
(D) Uğur Ekici,' (1) Murat Ferhat Ferhatoğlu² \\ ${ }^{1}$ College of Health Sciences, Gelisim University, Istanbul, Turkey \\ ${ }^{2}$ Department of General Surgery, Okan University Faculty of Medicine, Istanbul,Turkey
}

\begin{abstract}
Objectives: Pilonidal sinus disease causes chronic inflammation of the skin and subcutaneous fatty tissue, and it commonly localises in the sacrococcygeal region. This study evaluated the effects of hypertrichosis, family history, obesity and sex steroids in 298 patients with pilonidal sinus disease.

Methods: The medical records of 618 patients treated at the General Surgery Clinic of Malatya State Hospital for primary pilonidal sinus disease between January 2014 and December 2017 were evaluated retrospectively.

Results: Female sex and family histories of pilonidal sinus disease and hypertrichosis were significantly higher in patients with than without hypertrichosis $(p=0.030, p=0.035, p<0.001)$. The mean progesterone level was significantly lower in female patients with hypertrichosis than female patients without hypertrichosis $(p=0.003)$.

Conclusion: Being overweight or obese, having an occupation that requires long-time sitting and having a family history predisposed to developing pilonidal sinus disease.

Keywords: Hypertrichosis; obesity; pilonidal sinus; sex steroids.

Please cite this article as "Ekici U, Ferhatoğlu MF. Obesity, Hypertrichosis and Sex Steroids: Are these Factors Related to the Pilonidal Sinus Disease? Med Bull Sisli Etfal Hosp 2019;53(3):263-266".
\end{abstract}

$\mathrm{P}$ ilonidal sinus disease (PSD) is a common, chronic inflammatory disease of the skin and subcutaneous fatty tissue. PSD most often involves the sacrococcygeal region but can occur on the fingers or navel. PSD is mostly observed in a young adult male and is responsible for significant work and school absenteeism. ${ }^{[1]}$ PSD was first described by Mayo in 1833, and the first treatments were described by Anderson in 1844. ${ }^{[2]}$ Symptoms may vary from asymptomatic pits to abscesses that require drainage. ${ }^{[3]}$ The aetiology of PSD has been an ongoing subject of debate, but it is currently thought to be acquired. ${ }^{[4]}$ In 1992, Karydakis described the involvement of the skin and hair in the deep intergluteal cleft in the development of PSD. ${ }^{[5]}$ This study evaluated the effects of hypertrichosis, family history, obesity and sex steroids in 298 patients with PSD.

\section{Methods}

The medical records of 618 patients treated at the General Surgery Clinic of Malatya State Hospital for primary PSD between January 2014 and December 2017 were evaluated retrospectively. Three patients with psychiatric disorders, five with diabetes mellitus, seven with active abscesses, six receiving steroid therapy for other medical conditions and 13 without regular clinical follow-up were excluded from

Address for correspondence: Murat Ferhat Ferhatoğlu, MD. Okan Universitesi Tip Fakultesi, Genel Cerrahi Anabilim Dali, Istanbul, Turkey Phone: +90 5553214793 E-mail: ferhatferhatoglu@gmail.com

Submitted Date: February 07, 2019 Accepted Date: April 05, 2019 Available Online Date: August 26, 2019

${ }^{\circ}$ Copyright 2019 by The Medical Bulletin of Sisli Etfal Hospital - Available online at www.sislietfaltip.org

OPEN ACCESS This is an open access article under the CC BY-NC license (http://creativecommons.org/licenses/by-nc/4.0/). 
this study. The demographic characteristics, body mass index (BMI), family history of PSD, hypertrichosis, history of previous abscess formation, daily sitting time, preoperative antibiotic use, progesterone and testosterone levels, duration of surgery, hospital stay, postsurgical drain usage and drainage volume, time of suture removal and postoperative complications were evaluated in the remaining 584 patients.

Patients with acute inflammation were operated on after one week of treatment with anti-inflammatory drugs and antibiotics. All patients had a bath the night before the surgery and were admitted to the hospital on the day of the procedure. A single $1 \mathrm{~g}$ dose of prophylactic cefazolin sodium was administered before making the surgical incision. The operative field in the presacral area was shaved with an electric razor and cleaned with povidone-iodine. En bloc resection of the pilonidal sinus and healthy surrounding tissue was performed with the Karydakis procedure beginning with an asymmetric elliptical incision to the level of the presacral fascia, mobilization of the flap to the sacrococcygeal fascia and closure to complete the procedure.

Ethical Approval: All procedures in this study performed by following the Helsinki Declaration. Also, the Istanbul, Okan University, Ethical Board approved the study protocol (09.05.2018/94).

\section{Statistical Analysis}

SPSS 15.0 for Windows (SPSS Inc., Chicago, IL, USA) was used for the statistical analysis. Descriptive statistics were reported as means \pm standard deviation, medians, minimum and maximum. Categorical variables were reported as numbers and percentages. The Mann-Whitney $U$ test was used to compare differences in independent numerical variables with normal distributions. Differences in ratios were tested for significance by the chi-square test. Monte Carlo simulations were used to control for the influences of random variables. $\mathrm{P}<0.05$ were considered to be statistically significant.

\section{Results}

Of the 517 patients having sacrococcygeal pilonidal sinus without hypertrichosis, 67 patients having sacrococcygeal pilonidal sinus with hypertrichosis were evaluated. The patient characteristics and family history are shown in Table 1. There were no significant differences in age, sex, height, weight, or BMI. Female sex and family histories of PSD and hypertrichosis were significantly higher in patients with than without hypertrichosis $(p=0.030, p=0.035, p<0.001$ ). The mean progesterone level was significantly lower in female patients with hypertrichosis than the patients without hypertrichosis ( $p=0.003$, Table 2). Postoperative complications in patients with and without hypertrichosis, including wound infection, wound dehiscence, abscess formation,

Table 1. Patient characteristics and family history

\begin{tabular}{|c|c|c|c|c|c|}
\hline & \multicolumn{2}{|c|}{$\begin{array}{l}\text { Hypertrichosis } \\
\text { group }(n=67)\end{array}$} & \multicolumn{2}{|c|}{$\begin{array}{l}\text { Non-hypertrichosis } \\
\text { group }(n=517)\end{array}$} & \multirow[b]{2}{*}{$\mathbf{p}$} \\
\hline & Mean \pm SD & Min-Max/Median & Mean \pm SD & Min-Max/Median & \\
\hline Age & $23.5 \pm 5.9$ & $14-42 / 22$ & $24.4 \pm 7.0$ & $15-50 / 22$ & 0.446 \\
\hline Height & $171.2 \pm 7.8$ & $150-188 / 172$ & $172.1 \pm 7.4$ & $155-188 / 172$ & 0.379 \\
\hline Weight & $74.0 \pm 13.5$ & $45-115 / 73.5$ & $74.8 \pm 11.7$ & $40-102 / 74$ & 0.432 \\
\hline BMI & $\mathbf{n}$ & $\%$ & $\mathbf{n}$ & $\%$ & \\
\hline Family history of PSD & 41 & 40.2 & 54 & 28.1 & 0.035 \\
\hline Hypertrichosis in family & 63 & 61.8 & 8 & 4.2 & $<0.001$ \\
\hline Long-time sitting & 49 & 48.0 & 77 & 40.3 & 0.203 \\
\hline
\end{tabular}

Table 2. Progesterone level in men and testosterone levels in men and women

\begin{tabular}{|c|c|c|c|c|c|}
\hline & \multicolumn{2}{|c|}{$\begin{array}{l}\text { Hypertrichosis } \\
\text { group }(n=67)\end{array}$} & \multicolumn{2}{|c|}{$\begin{array}{l}\text { Non-hypertrichosis } \\
\text { group }(n=517)\end{array}$} & \multirow[b]{2}{*}{$\mathbf{p}$} \\
\hline & Mean \pm SD & Min-Max/Median & Mean \pm SD & Min-Max/Median & \\
\hline Female progesterone & $0.94 \pm 0.32$ & $0.6-1.9 / 0.9$ & $1.15 \pm 0.31$ & $0.7-1.9 / 1$ & 0.003 \\
\hline Female testosterone & $0.52 \pm 0.25$ & $0.2-1.1 / 0.5$ & $0.52 \pm 0.20$ & $0.2-1 / 0.5$ & 0.743 \\
\hline Male testosterone & $4.02 \pm 1.57$ & $1.1-7.9 / 3.9$ & $3.99 \pm 1.99$ & $1.2-15 / 3.8$ & 0.360 \\
\hline
\end{tabular}


Table 3. Postoperative complications

\begin{tabular}{|c|c|c|c|c|c|}
\hline & \multicolumn{2}{|c|}{$\begin{array}{l}\text { Hypertrichosis } \\
\text { group }(n=67)\end{array}$} & \multicolumn{2}{|c|}{$\begin{array}{l}\text { Non-hypertrichosis } \\
\text { group }(n=517)\end{array}$} & \multirow[b]{2}{*}{$\mathbf{p}$} \\
\hline & $\mathbf{n}$ & $\%$ & $\mathbf{n}$ & $\%$ & \\
\hline \multicolumn{6}{|l|}{ Postoperative complications } \\
\hline No complications & 160 & 78.8 & 320 & 83.9 & \\
\hline Other & 2 & 0.98 & 2 & 0.52 & \\
\hline Wound infection & 27 & 13.3 & 43 & 11.2 & \\
\hline Wound dehiscence & 2 & 0.98 & 2 & 0.52 & 0.069 \\
\hline Abscess formation & 7 & 3.44 & 7 & 1.83 & \\
\hline Flap necrosis & 0 & 0.0 & 1 & 0.26 & \\
\hline Postspinale Cephalalgia & 5 & 2.46 & 6 & 1.57 & \\
\hline
\end{tabular}

flap necrosis, and cephalalgia after spinal anaesthesia in patients with and without hypertrichosis, were not significantly different ( $p=0.069$, Table 3 ).

\section{Discussion}

A family history, male gender, sex hormone level, being a young adult, obesity, local trauma, hypertrichosis and hyperhidrosis are known risk factors for PSD. ${ }^{[6-8]}$ The mean ages of patients in this study were $23.5 \pm 5.9$ years in patients with and $24.4 \pm 7.0$ years in patients without hypertrichosis. The mean BMls were over $25 \mathrm{~kg} / \mathrm{m}^{2}$ in both groups, which means that the majority of the patients were overweight or obese. Age and BMI were in line with other reports. Bradley reported that overweight contributed to $37 \%$, and obesity to and $13 \%$, of all pilonidal sinus cases. ${ }^{[8]}$ Arda et al. ${ }^{[9]}$ reported that $67.1 \%$ of PSD patients were overweight or obese, and both conditions were identified as risk factors for PDS. Other studies by Akinci et al. ${ }^{[10]}$ and Bolandparvaz et al. ${ }^{[11]}$ have found that obesity (BMI $\left.>25 \mathrm{~kg} / \mathrm{m}^{2}\right)$ significantly increased the risk of PSD. We believe that the wet, fragile deep intergluteal skin of obese and overweight patients predisposes for PSD. Dead hair insertion into existing sinus pits or skin abrasions that arises from rotational movements of the buttocks during walking is the main problem in overweight and obese people. ${ }^{[12]}$

Chamberlain and Vawter were the first to describe a familial tendency of PSD in 1974, ${ }^{[13]}$ and this has been confirmed by Bradley, ${ }^{[8]}$ Onder A et al. ${ }^{[14]}$ and Doll et al. ${ }^{[15]}$ who reported that $23 \%$ to $38 \%$ of PSD patients had a family history and concluded that it was a predisposing factor. In this study, family history of the disease is significantly more frequent in patients having hypertrichosis $(p=0.035)$, and hypertrichosis in family members was significantly more frequent in patients with hypertrichosis $(p<0.001)$. We believe that familial hypertrichosis may be a predisposing genetic factor for PSD, but further study is needed for confirmation.
Bolandparvaz et al. ${ }^{[11]}$ reported that more than four hours of daily sitting increased the risk of PSDS, and occupations that require sitting for long periods of time were found by Kayadibi $A$ et al. ${ }^{[16]}$ to predispose for PSD. In this study, sitting time was not significantly different in patients with or without hypertrichosis, but $48 \%$ of the patients with hypertrichosis and $40.3 \%$ of those without hypertrichosis spent a long-time sitting every day. That is consistent with published data that occupations requiring long-term daily sitting may facilitate PSD.

Female testosterone levels were not significantly different in patients with or without hypertrichosis, but female progesterone was significantly higher in patients with hypertrichosis. Steroid hormones other than androgens have a mild effect on hair growth, but it is difficult to assess the direct effects of progesterone because it influences androgen binding. ${ }^{[17]}$ Sex steroids may have a mild effect on hypertrichosis that is indirectly related to PSD. Prospective, randomized controlled studies with large patient samples are needed to investigate this effect.

Surgical wound infection was the most common complication in both hypertrichosis and non-hypertrichosis patients, but the rates of occurrence were not significantly different. The fragility of intergluteal skin, excessive sweating and high BMI may have increased the risk of wound complications. ${ }^{[18]}$

\section{Conclusion}

The study limitations include its retrospective nature and the limited number of patients makes it difficult to draw firm conclusions. However, the results indicate that being overweight or obese, having an occupation that requires long-time sitting and having a family history predisposed to developing PSD. High progesterone level may create a tendency for this disease, but the relationship requires further investigation in larger patient series. 


\section{Disclosures}

Ethics Committee Approval: Istanbul Okan University, Ethical Board approved the study protocol (09.05.2018/94).

Peer-review: Externally peer-reviewed.

Conflict of Interest: None declared.

Authorship Contributions: Concept - U.E.; Design - U.E.; Supervision - U.E.; Materials - U.E.; Data collection \&/or processing - U.E.; Analysis and/or interpretation - M.F.F.; Literature search M.F.F.; Writing - U.E.; Critical review - M.F.F.

\section{References}

1. Altintoprak F, Gundogdu K, Ergonenc T, Dikicier E, Cakmak G, Celebi F. Retrospective review of pilonidal sinus patients with early discharge after Limberg flap procedure. Int Surg 2014;99:28-34.

2. Hap W, Frejlich E, Rudno-Rudzińska J, Kotulski K, Kurnol K, Hap $\mathrm{K}$, et al. Pilonidal sinus: finding the righttrack for treatment. Pol Przegl Chir 2017;89:68-75. [CrossRef]

3. YildizT, Elmas B, Yucak A, Turgut HT, Ilce Z. Risk Factors for Pilonidal Sinus Disease in Teenagers. Indian J Pediatr 2017;84:134-8.

4. Afşarlar CE, Yılmaz E, Karaman A, Karaman I, Ozgüner IF, Erdoğan $D$, et al. Treatment of adolescent pilonidal disease with a new modification to the Limberg flap: symmetrically rotated rhomboid excision and lateralization of the Limberg flap technique. J Pediatr Surg 2013;48:1744-9. [CrossRef]

5. Karydakis GE. Easy and successful treatment of pilonidal sinus after explanation of its causative process. Aust N Z J Surg 1992;62:385-9. [CrossRef]

6. Carnali M, Ronchi R, Finocchi L, Meletani T, Capesciotti SS, Paggi B. Retrospective study on the use of negative pressure wound therapy in the treatment of pilonidal cysts (sinus pilonidalis) operated on using an open technique or complicated by dehiscence of the surgery site through sepsis. Acta Vulnologica 2016;14:24-39.

7. Cubukçu A, Gönüllü NN, Paksoy M, Alponat A, Kuru M, Ozbay O. The role of obesity on the recurrence of pilonidal sinus disease in patients, who were treated by excision and Limberg flap transposition. Int J Colorectal Dis 2000;15:173-5. [CrossRef]

8. Bradley L. Pilonidal sinus disease: a review. Part one. J Wound Care 2010;19:504-8. [CrossRef]

9. Arda IS, Güney LH, Sevmiş S, Hiçsönmez A. High body mass index as a possible risk factor for pilonidal sinus disease in adolescents. World J Surg 2005;29:469-71. [CrossRef]

10. Akinci OF, Bozer M, Uzunköy A, Düzgün SA, Coşkun A. Incidence and aetiological factors in pilonidal sinus among Turkish soldiers. Eur J Surg 1999;165:339-42. [CrossRef]

11. Bolandparvaz S, Moghadam Dizaj P, Salahi R, Paydar S, Bananzadeh M, Abbasi HR, et al. Evaluation of the risk factors of pilonidal sinus: a single center experience. Turk J Gastroenterol 2012;23:535-7. [CrossRef]

12. Saber A, Bayumi EK. Sacrococcygeal Pilonidal Sinus Disease. In: Recent Clinical Techniques, Results, and Research in Wounds. Springer, Cham; 2017. [CrossRef]

13. Chamberlain JW, Vawter GF. The congenital origin of pilonidal sinus. J Pediatr Surg 1974;9:441-4. [CrossRef]

14. Onder A, Girgin S, Kapan M, Toker M, Arikanoglu Z, Palanci Y, et al. Pilonidal sinus disease: risk factors for postoperative complications and recurrence. Int Surg 2012;97:224-9. [CrossRef]

15. Doll D, Matevossian E, Wietelmann K, Evers T, Kriner M, Petersen S. Family history of pilonidal sinus predisposes to earlier onset of disease and a 50\% long-term recurrence rate. Dis Colon Rectum 2009;52:1610-5. [CrossRef]

16. Kayadibi A, Hasanoglu A, Akkus MA. The relationship between occupation, age, sex, body mass index and pilonidal sinus disease. Turkish Med J 2007;1:123-7.

17. Brown J, Farquhar C, Lee O, Toomath R, Jepson RG. Spironolactone versus placebo or in combination with steroids for hirsutism and/ or acne. Cochrane Database Syst Rev 2009:CD000194. [CrossRef]

18. Youssef AT. The value of superficial parts and endoanal ultrasonography in evaluating pilonidal disease and exclusion of perianal sepsis. J Ultrasound 2015;18:237-43. [CrossRef] 